\title{
TRIGONELLA FOENUM-GRAECUM L. EXHIBITS ESTROGENIC EFFECT THROUGH PRESENILIN 2 GENE EXPRESSION IN THE BREAST CANCER CELL LINE MCF-7
}

\author{
KURNIA AGUSTINI ${ }^{1}$, MICHAEL WINK ${ }^{2}$, WAHONO SUMARYONO ${ }^{1}$, FRANS SUYATNA ${ }^{3}$, NURJATI CHAIRANI SIREGAR ${ }^{3}$ \\ ${ }^{1}$ Center for Pharmaceutical and Medical Technology, Agency for the Assessment and Application of Technology, LAPTIAB, PUSPIPTEK \\ Area, Serpong, South Tangerang 15314, Indonesia. ${ }^{2}$ Department of Biology, Institut für Pharmazie und Molekulare Biotechnologie (IPMB), \\ Universitaet Heidelberg, Im Neuenheimer Feld 364, D-69120 Heidelberg, Germany. ${ }^{3}$ Department of Pharmacology, Faculty of Medicine, \\ University of Indonesia, Salemba Street No.6. Jakarta 10430, Indonesia. Email: kurnia.agustini@bppt.go.id
}

Received: 27 August 2018, Revised and Accepted: 26 November 2018

\section{ABSTRACT}

Objective: The objective of this study is to investigate the estrogenic and antiestrogenic activity of Fenugreek seeds, Trigonella foenum-graecum L. in the estrogen-dependent breast cancer cell line, MCF-7, including its effect on the expression of estrogen-dependent presenilin 2 ( $p S 2$ ) gene.

Methods: An activity guided fractionation was carried out with extracts from fenugreek seeds in MCF-7 cells. Cytotoxic activity assays were conducted with 3-(4,5-dimethylthiazol-2-yl)-2,5-diphenyltetrazolium (MTT) assay. Most fractions were also tested also tested in media with estradiol 10 nM We also analysed the expression of $p S 2$ gene. For the analysis of $p S 2$ gene expression we employed PCR primers for $p S 2$ and for $\beta$-actin as a housekeeping gene using real-time polymerase chain reaction (RT-PCR).

Results: Based on cytotoxic activity assay in MCF-7, the active fractions are ethyl acetic fraction and its phases ethyl acetic (EA) 2 and EA 2.2. The most active fraction was EA $2.2\left(\mathrm{IC}_{50}=27.129 \mathrm{ppm}\right)$, which exhibited a biphasic effect; at low concentrations, it stimulated the growth, and at high concentrations it showed strong cytotoxic effects. EA2.2 fraction in concentration 20 ppm, also could induce $p S 2$ gene expression in media with and without estrogen.

Conclusion: The most active fraction was the ethyl acetate phase and further subfractions. The most active fraction also induced the expression of pS2 gene which was studied by RT-PCR.

Keywords: Estrogenic effect, MCF-7, Presenilin 2 gene, Trigonella-foenum graecum L.

(C) 2019 The Authors. Published by Innovare Academic Sciences Pvt Ltd. This is an open access article under the CC BY license (http://creativecommons. org/licenses/by/4. 0/) DOI: http://dx.doi.org/10.22159/ajpcr.2019.v12i1.29340

\section{INTRODUCTION}

Fenugreek seeds or Foenigraeci semen are the dried seeds from Trigonella foenum-graecum (TFG) L., Fabaceae [1,2]. Fenugreek seeds were assumed to have estrogen-like effects because they contain some steroids, for example, diosgenin, a precursor for sexual hormones [3], yamogenin [4], gitogenin, tigogenin, and trigoneoside (saponin-like estrogen) isomers [2]. Fenugreek seeds contain $0.8-2.2 \%$ diosgenin as aglycone [5]. In addition, fenugreek seeds also contain fatty oil 20-30\%, alkaloids (trigonelline, an pyridine alkaloid, gentianin, and karpain), flavonoids, for example, vitexin in glycoside or ester form, isovitexin, orientin, vicenin, quercetin and luteolin [1], essential oil, nicotinamide, choline, and mucilage [3], and also galaktomannan [6]. Fenugreek seeds can induce uterine contractions; therefore, it should not be consumed during pregnancy [2]

Phytoestrogen is a compound in plants that exert estrogenic or antiestrogenic-like effects on animals and humans [7]. They bind weakly to estrogen receptor (ER) to induce transcription of estrogen-responsive target genes in a dose-dependent manner [8]. The relative affinities of phytoestrogens for ER are $>102-105$-fold lower than $17 \beta$-estradiol (E2), which is an important factor when considering dietary intake of phytoestrogens and their subsequent circulating concentrations [8]. Active phytoestrogens have been discovered among isoflavonoids, for example, genistein, biochanin A, and daidzein; coumestan, for example, coumestrol; stilbenes, for example, resveratrol; lignans, for example, enterolactone, matairesinol, and enterodiol; and steroidal sapogenin, for example, dammarane and diosgenin $[9,10]$. Phytoestrogens are being used as an alternative for hormone replacement therapy to help reducing the symptoms of menopause and premenstrual syndrome. It can be used in a long-term period until the body has adapted to the new hormone levels [11]. Nowadays, many phytoestrogens are being investigated as natural selective ER modulators (SERMs), specifically in the treatment of hormone-dependent breast cancers. Some phytoestrogens which are SERM without action on the uterus but with specific effects on the hypothalamus/pituitary complex and bones are presently the focus of clinical interest [12]. Phytoestrogens function as estrogen agonists in certain tissues but exhibit antiestrogenic effects in others [13]. According to Johnston, the ideal SERM should exhibit greater binding affinity for ER and have the ability to antagonize estrogen-dependent growth of breast cancer cells [14].

To date, few plant-derived SERMs have been evaluated in clinical trials, although a number of herbal remedies such as extracts of black cohosh and red clover are touted for the relief of postmenopausal and premenstrual symptoms [15]. The precise constituents of these extracts that might be responsible for such pharmacological effects are partly known, and isoflavonoids such as genistein have been reported to display both estrogenic and antiestrogenic effects [16]. Genistein is about 100 -fold less potent than E2 in its ability to bind to ER, but its circulating concentrations in individuals consuming moderate amounts of soy foods are nearly 1000-fold higher than peak levels of endogenous E2 [17]. Interestingly, Asian women who consume a soy-rich diet have about a 6-fold lower risk of developing breast cancer than their western counterparts [18] and population-based studies have suggested that consumption of a phytoestrogen-rich diet is protective against prostate and bowel cancer, as well as cardiovascular disease [19]. Hence, it is possible that these phytoestrogens function as chemopreventive agents, and because human consumption of phytoestrogens is common, plant-derived agents are promising candidates for clinical trials [9]. 
In our previous study, we could show that fenugreek seed has estrogenic activity in rats [20]. The estrogenic activity of an ethanolic extract of fenugreek seeds was tested in two experimental models, that is, ovariectomized adult White female rats and immature rats (age of 19 days). The extract had estrogenic effects on vaginal cornification, stimulated E2, and follicle-stimulating hormone (FSH) production of immature rats, decreased FSH level on ovariectomized rats, increased uterine, and mammary gland proliferation. This potency needs to be explored in more detail to find a phytoestrogen as an alternative treatment for hormonal disruption such as menopause. Besides, phytoestrogens are interesting candidates also for natural SERMs to treat breast cancer.

The present study investigated the cytotoxicity of some fractions of fenugreek seeds in the estrogen-dependent breast cancer cell line, MCF-7 in media with or without E2. This cell line allows the identification of estrogen agonist. Furthermore, the expression of an estrogen-dependent gene, presenilin 2 (pS2) will be monitored as a marker for agonistic and antagonistic ligands [21].

\section{METHODS}

\section{Samples preparation}

Fenugreek seeds were obtained from Tawangmangu, Central Java, Indonesia, and determinate by Research Centre for Biology, Indonesian Institute of Sciences, with document no. 252/IPH.1.02/If.8/2008. Seeds were dried and ground; then extracted with methanol. The methanolic extract was separated with $\mathrm{n}$-hexane, ethyl acetic (EA), and n-butanol. Every phase was dried in a vacuum rotary evaporator. Each fraction then analyzed with 3-(4,5-dimethylthiazol-2-yl)-2,5-diphenyltetrazolium (MTT) assay on MCF7. The active fractions were separated using column chromatography with suitable eluents. Further separation followed the activity of the fraction (activity guided fractionation). Fractionation process can be seen in Fig. 1.

\section{Cell culture}

The cell line MCF-7 (human breast adenocarcinoma) was obtained from The Laboratory for Development of Agro Industry and Biomedical Technology (LAPTIAB-BPPT) Indonesia, and Department Biology, Institute of Pharmacy and Molecular Biotechnology (IPMB), Heidelberg University.

MCF-7 cells were routinely maintained and grown in $75 \mathrm{~cm}^{2}$ flasks at $37^{\circ} \mathrm{C}, 5 \% \mathrm{CO}_{2}$ and in a $95 \%$ humidified atmosphere. The growth medium was prepared as follows: RPMI 1640, Gibco life Technologies with phenol red and $2 \mathrm{mM}$ glutamine, $100 \mathrm{U} / \mathrm{ml}$ penicillin, $0.1 \mathrm{mg} / \mathrm{ml}$ streptomycin, $1 \mathrm{mM}$ sodium pyruvate, and supplemented with $10 \%$ fetal bovine serum (FBS) (FBS, Gibco Life Technologies) that had been heat-inactivated at $56^{\circ} \mathrm{C}$ for $30 \mathrm{~min}$. Passaging of cells was carried out using $4 \mathrm{ml}$ of trypsin-ethylenediaminetetraacetic acid (EDTA) at room temperature for $3 \mathrm{~min}$. Then, $10 \mathrm{ml}$ media with $10 \%$ FBS were added to dilute trypsin in the cell culture. After centrifugation, the pelleted cells were distributed into new culture flasks.

\section{Cytotoxicity test with MTT method}

Cells were plated into 96 -well plates $(10,000$ cells/well) in medium RPMI with phenol red containing $10 \mathrm{FBS}, 100 \mathrm{U} / \mathrm{ml}$ penicillin, $0.1 \mathrm{mg} / \mathrm{ml}$ streptomycin, and $1 \mathrm{mM}$ sodium pyruvate, then incubated for $24 \mathrm{~h}$ at $37^{\circ} \mathrm{C}, 5 \% \mathrm{CO}_{2}$, and in a $95 \%$ humidified atmosphere. After $24 \mathrm{~h}$, samples (extracts and phases of TFG) were added to the growth medium in different concentration and incubated for another $24 \mathrm{~h}$. Assays were done in a wide range of concentrations, from $10 \mathrm{ppm}$ to $500 \mathrm{ppm}$.

After $24 \mathrm{~h}$ of treatment, cells were washed with phosphate buffer saline (PBS). Then, the MTT solution in the medium was added followed by incubation for $4 \mathrm{~h}$. In living cells, crystals of formazan blue will be formed. The reaction was stopped by adding sodium dodecyl sulfate into every well. The plate was left in the dark for $12 \mathrm{~h}$ (overnight), and the intensity of the color formed was measured by an ELISA reader at $570 \mathrm{~nm}$

\section{Cell growth and proliferation in media with $\mathrm{E} 2$}

Cells were plated into 96-well plates (30,000 cells/well) in an estrogenfree culture medium with $10 \%$ stripped-FBS. Stripped FBS was prepared as follows; DCC solution consisted of 7.14 g of charcoal (Norit A), $714 \mathrm{mg}$ of dextran T70, and $628 \mathrm{mg}$ of $\mathrm{NaCl}$ dissolved in $50 \mathrm{ml} \mathrm{H}_{2} \mathrm{O} .50 \mathrm{ml} \mathrm{FBS}$ were mixed with $1.5 \mathrm{ml}$ DCC solution followed by centrifugation at $\times 2100 \mathrm{~g}$ for $30 \mathrm{~min}$. The supernatant was incubated with another $1.5 \mathrm{ml}$ DCC solution for further $30 \mathrm{~min}$ at $37^{\circ} \mathrm{C}$ and centrifuged at $\times 210 \mathrm{~g}$ for another $30 \mathrm{~min}$. The stripped serum was sterilized by filtering through a $0.22 \mu \mathrm{m}$ filter and kept frozen at $-20^{\circ} \mathrm{C}$ until use.

The cells were incubated for $48 \mathrm{~h}$, and the medium was changed for every $24 \mathrm{~h}$ with or without test compounds and E2 $(10 \mathrm{nM}$, as a positive control). After $48 \mathrm{~h}$ of treatment, the cells were washed twice with PBS. Neutral red $(5 \mathrm{mg} / 100 \mathrm{ml}$ in medium) was added, followed by incubation for $3 \mathrm{~h}$ at $37^{\circ} \mathrm{C}, 5 \% \mathrm{CO}_{2}$, and in a $95 \%$ humidified atmosphere.

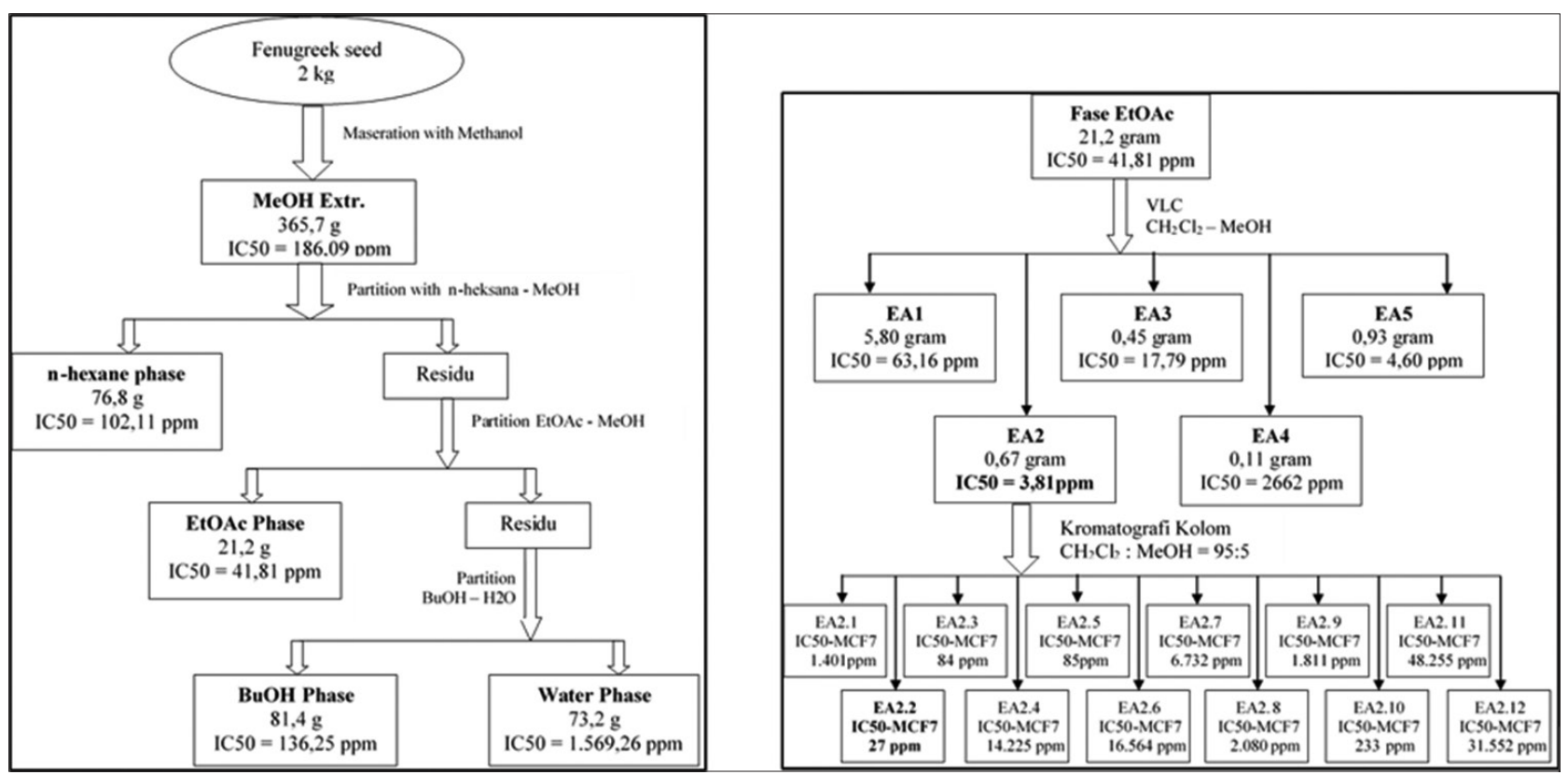

Fig. 1: Fractionation followed by activity on MCF7 cells 
After incubation with neutral red, cells were washed twice with PBS. Subsequently, the dye is dissolved with $150 \mu \mathrm{l}$ of $\mathrm{HCl}$-isopropanol $(0.04$ $\mathrm{N} \mathrm{HCl}, 100 \%$ 2-propanol) and well homogenized on a plate shaker for 30 min. Finally, the absorbance was measured with an ELISA reader at $540 \mathrm{~nm}$.

\section{Cell growth for $p S 2$ expression [22]}

Cells were plated into 6 well plates $(200,000$ cells/well) in an estrogenfree culture medium as described above. The medium was changed every $24 \mathrm{~h}$ with test compounds. After $48 \mathrm{~h}$ of treatment, the cells were washed twice with PBS. Cells were trypsinized using $300 \mu \mathrm{l} /$ well of trypsin-EDTA at room temperature for $3 \mathrm{~min} .2 \mathrm{ml}$ medium (10\% FBS) was added to dilute trypsin. Cells were centrifuged and pellets obtained were immediately used for RNA extraction.

\section{Extraction and purification of RNA transcripts [22]}

RNA was isolated with RNeasy Mini Kit (Qiagen), DNA was degraded with RNase-Free DNase set (Qiagen). RNeasy Mini Kit is a suitable system to isolate and clean total RNA from small quantities of cell material. This simple and fast method allows the isolation of up to $100 \mu \mathrm{g}$ of total RNA from $<10^{7}$ cells. The isolation starts by loosening the pellets by flicking. A $350 \mu \mathrm{L}$ standardized buffer RTL is added to the sample $(10 \mu \mathrm{l}$ $\beta$-mercaptoethanol [14.3 M] is added to $1.990 \mathrm{ml}$ RTL buffer). The homogenization was done by passing the lysate 5 times through a gauge needle. An equal volume of $70 \%$ ethanol is added to the homogenized lysate and mixed well. The sample $(700 \mu \mathrm{L})$ is applied onto the column and centrifuged $>\times 8000 \mathrm{~g}$ for $15 \mathrm{~s}$. The first wash step is performed by adding $350 \mu \mathrm{L}$ buffer RW1 onto the column and centrifuged $>\times 8000 \mathrm{~g}$ for $15 \mathrm{~s}$. Residual DNA was digested by $80 \mu \mathrm{L}$ of DNase I solution $(10 \mu \mathrm{L}$ 2.72 Kunitz U/ $\mu \mathrm{L}$ DNase) to $70 \mu \mathrm{L}$ buffer RDD directly onto the column and incubated for $15 \mathrm{~min}$ at room temperature. After digestion, $350 \mu \mathrm{L}$ buffer RW1 is added into the column and centrifuged $>\times 8000 \mathrm{~g}$ for $15 \mathrm{~s}$. Washing steps were done twice by adding $500 \mu \mathrm{L}$ buffer RPE and centrifuged $>\times 8000 \mathrm{~g}$ for $15 \mathrm{~s}$. To eluate, the adsorbed RNA from the column $30 \mu \mathrm{L}$ of RNase-free water is added and centrifuged $>\times 8000 \mathrm{~g}$ for $90 \mathrm{~s}$. The obtained total RNA is immediately placed at $-80^{\circ} \mathrm{C}$

The concentration of total RNA was estimated by absorption at $260 \mathrm{~nm}$ using NanoDrop Spectrophotometer (ND-1000 V3.30). To check the quality of total RNA electrophoresis on agarose gels $(0.1 \%$ ethidium bromide) was carried out with $100 \mathrm{~V}$ for $10 \mathrm{~min}$.

\section{Conversion of mRNA to complementary DNA (cDNA) [22]}

mRNA was converted to cDNA, which is more stable to degradation and not attacked by ubiquitous RNAse. mRNA was reverse transcribed with Avian-Myeloblastosis-Virus reverse transcriptase (AMV-RTase) and kept at $20^{\circ} \mathrm{C}$ until real-time-polymerase chain reaction (RT-PCR) analysis. Protocol for reverse transcription: Step 1: PCR tube contains $1 \mu \mathrm{g}$ total RNA, $0.5 \mu \mathrm{g}$ oligo (dT) and $5.6 \mu$ l diethyl pyrocarbonate- $\mathrm{H}_{2} \mathrm{O}$; it was placed in RT-PCR $70^{\circ} \mathrm{C}$ for $5 \mathrm{~min}$. Step 2: Then $1 \mathrm{mM}$ dNTP, 15 units reverse transcriptase (AMV-RTase), 20 units RNase inhibitor $\left(\mathrm{RNasin}^{\circledast}\right.$ ), and $5 \mathrm{mM} \mathrm{MgCl}_{2}, 4 \mu \mathrm{l}$ buffer $\times 5$ (contains $10 \mathrm{mM}$ Tris- $\mathrm{HCl}$ $\mathrm{pH}$ 7.0, $50 \mathrm{mM} \mathrm{KCl}$, and $0.1 \%$ Triton ${ }^{\circledR} \mathrm{X}-100$ ) were add, then RT-PCR was carried out. cDNA obtained was stored at $-20^{\circ} \mathrm{C}$.

\section{Analysis of the $p S 2$ expression [22]}

The primer for $p S 2$ and $\beta$-actin as a housekeeping gene was obtained from eurofins-mwg-operon $\AA$.

The sequence for $p S 2$ forward (f) and reverse ( $\mathrm{r}$ ) primers is: $p S 2$ (f) 5'- CAT GGA GAA CAA GGT GAT CTG -3' pS2 (r) 5'- CAG AAG CGT GTC TGA GGT GTC-3'

The sequence for $\beta$-actin forward (f) and reverse ( $\mathrm{r}$ ) primers is: $\beta$-actin (f) 5'-TCA TGA AGT GTG ACG TGG ACA TCC GC-3' $\beta$-actin (r) 5'-CCT AGA AGC ATT TGC GGT GGA CGA TG-3'

RT-PCR conditions for both genes: Each PCR tube $(20 \mu \mathrm{l})$ contained $1 \mu \mathrm{l}$ cDNA, $200 \mu \mathrm{M}$ dNTP, $400 \mathrm{nM} p S 2$ or $\beta$-actin primers (f, r), PCR buffer
(10 mM Tris- $\mathrm{HCl} 50 \mathrm{mM} \mathrm{KCl}, 1.5 \mathrm{mM} \mathrm{MgCl}, 0.5 \%$ Triton X-100, and $\mathrm{pH}$ 8.5) and $1 \mathrm{U}$ Taq DNA polymerase. PCR products were analyzed by agarose gel electrophoresis.

\section{RESULTS AND DISCUSSION}

\section{Cell growth and proliferation study}

Extracts were prepared from fenugreek seeds and subjected to activity guided fractionation. Results of corresponding cytotoxicity assays with MCF-7 are illustrated in Table 1.

The most active fraction was EA2.2 $\left(\mathrm{IC}_{50}=27.129 \mathrm{ppm}\right)$, which exhibited a biphasic effect; at low concentrations, it stimulated the growth, and at high concentrations it showed strong cytotoxic effects.

\section{Cell growth of MCF 7 in medium with E2}

To confirm the estrogen dependence of MCF-7 cells, they were grown for $24 \mathrm{~h}$ in a RPMI medium without phenol red, with $10 \%$ strippedFBS containing $10 \mathrm{nM} \mathrm{B-E2.} \mathrm{Fig.} 2$ illustrates that E2 stimulated the proliferation of MCF-7 cells.

Table 1: Cytotoxic activity $\mathrm{IC}_{50}(\mathrm{ppm})$ of some fractions of fenugreek seeds in MCF-7 cells determined with MTT assay

\begin{tabular}{ll}
\hline Samples & IC $_{50}(\mathbf{p p m})$ \\
\hline Methanolic extract & 186.09 \\
*EA fraction & 41.81 \\
Butanolic fraction & 136.25 \\
Hexane fraction & 102.11 \\
Aqueous fraction & $1,569.26$ \\
Phase EA.1 & 82.45 \\
*Phase EA.2 & 3.26 \\
Phase EA.3 & 18.36 \\
Phase EA.4 & 3303 \\
Phase EA.5 & 5.44 \\
Phase EA.2.1 & $1,401.670$ \\
*Phase EA.2.2 & 27.129 \\
Phase EA.2.3 & 84.602 \\
Phase EA.2.4 & $14,225.712$ \\
Phase EA.2.5 & 85.137 \\
Phase EA.2.6 & $16,564,495$ \\
Phase EA.2.7 & $6,793,863,053$ \\
Phase EA.2.8 & ND \\
Phase EA.2.9 & $1,811,609$ \\
Phase EA.2.10 & 233.17 \\
Phase EA.2.11 & $48,255,220,427$ \\
Phase EA.2.12 & $31,522,640$ \\
\hline
\end{tabular}

MTT: 3-(4,5-dimethylthiazol-2-yl)-2,5-diphenyltetrazolium

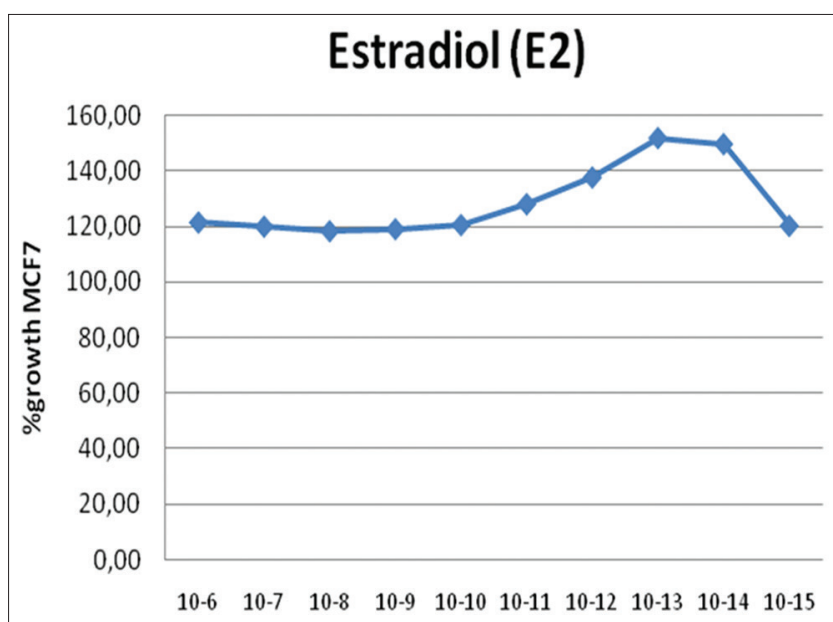

Fig. 2: Influence of different concentrations of estradiol on the growth of MCF-7 cells 


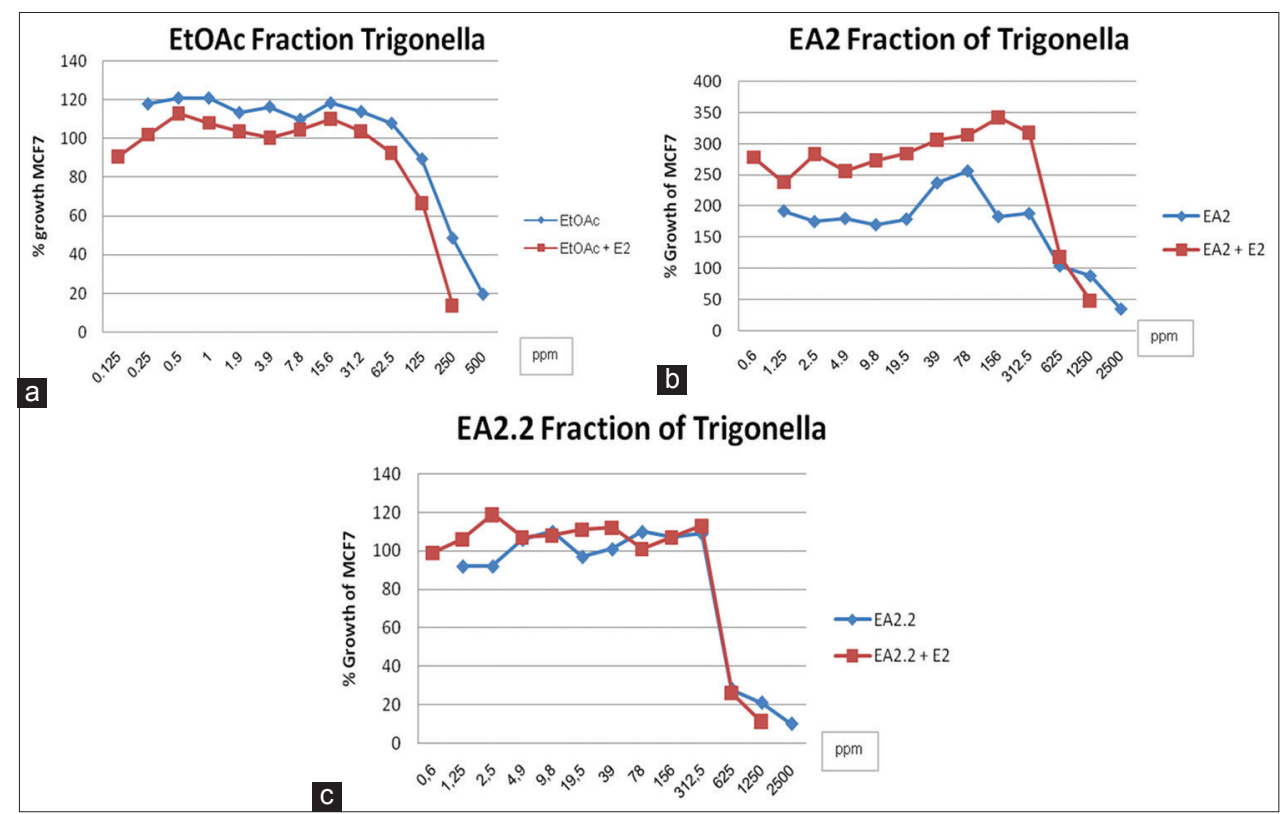

Fig. 3: (a-c) Effects of some fractions of fenugreek in the presence and absence of $10 \mathrm{nM}$ estradiol on the growth of MCF-7

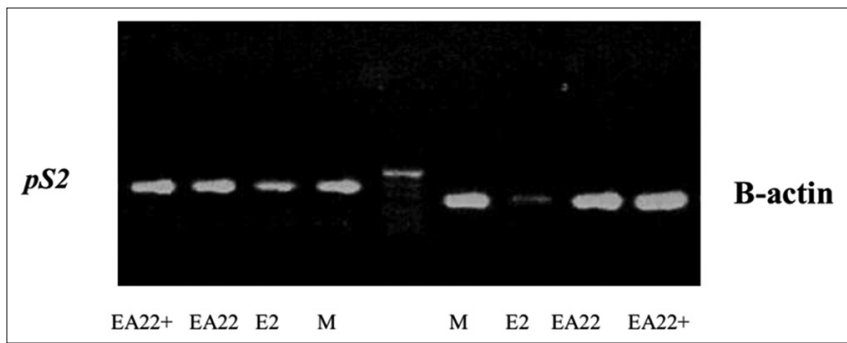

Fig. 4: Induction of presenilin 2 (pS2) expressions in MCF-7 cells. Polymerase chain reaction products of pS2 and $\beta$-actin were separated by agarose gel electrophoresis. $\mathrm{M}=$ medium with $10 \% \mathrm{~S}$-FBS, estradiol (E2) $=10 \mathrm{nM} \mathrm{E2,} \mathrm{EA2.2=20} \mathrm{ppm} \mathrm{fraction} \mathrm{of}$ fenugreek, EA2.2+=20 ppm fraction of fenugreek with presence of E2 $10 \mathrm{nM}$

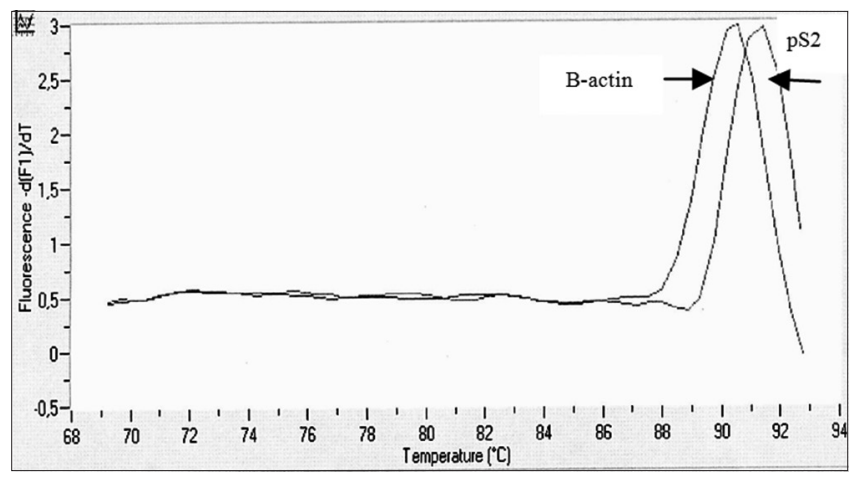

Fig. 5: Melting curves for presenilin 2 and $\beta$-actin

This system was used to detect extracts and fractions which function as ER agonists. MCF-7 cells were treated $48 \mathrm{~h}$ with selected fractions in medium with or without $10 \mathrm{nM} \mathrm{E2}$. Results in Fig. 3 show that at high dose, the extract from fenugreek seeds could inhibit the proliferation of MCF-7 cells. Both assays in medium with or without E2 $10 \mathrm{~nm}$ gave the same pattern. Proliferation inhibition in media with E2 occurred at lower $\mathrm{IC}_{50}$ than in media without E2 (Table 2). Therefore, we assume that a competition of fenugreek seed fractions and E2 exists at the ER of MCF-7 cells.
Table 2: Table of Inhibitory concentrations ( $\left.\mathrm{IC}_{50}[\mathrm{ppm}]\right)$ of selected fractions in MCF-7 cells in the presence of 10 nM E2

\begin{tabular}{llll}
\hline \multirow{2}{*}{ Samples } & Without E2 & With E2 \\
\cline { 2 - 2 } & $\mathbf{I C}_{\mathbf{5 0}} \mathbf{( p p m )}$ & $\mathbf{I C}_{\mathbf{5 0}} \mathbf{( p p m )}$ \\
\hline EtOAc fraction & 244 & 119.9 \\
EA2 fraction & 1,751 & 714 \\
EA2.2 fraction & 637 & 580.85 \\
\hline E2: Estradiol & &
\end{tabular}

According to Johnston, an ideal SERM, should exhibit greater binding affinity for ER and should, therefore, be able to antagonize estrogendependent growth of breast cancer cells. The data in Table 2 show that the antiproliferative activity of some fenugreek fractions in media with E2 had been greater than in media without E2. From these data, we can conclude that fenugreek fraction EA2 has the ability to antagonize E2 in MCF-7 cells.

\section{Analysis of $p S 2$ expression}

RT-PCR analysis was carried out to determine the relative copy number of $p S 2$ and $\beta$-actin mRNA. PCR products were analyzed by agarose gel electrophoresis (Fig. 4). Presenilin-2 ( $p S 2$ ) is a protein that is expressed in estrogen-responsive cells after stimulation with E2 (Fig. 5).

The relative expression data show that pS2 was up-regulated in all cells treated with E2 and phytoestrogens in comparison to untreated controls by a mean factor of 1691 (S E range is 1357-2062).

EA2.2 fraction of Fenugreek seed (20 ppm) could induce pS2 gene expression in estrogen and estrogen-free medium (Fig. 6).

\section{CONCLUSION}

This study showed that the extracts from fenugreek seeds especially the ethyl acetic phase had cytotoxic effects in MCF-7 cells. Its IC ${ }_{50}$ in MCF-7 grown in media with $10 \mathrm{nM} \mathrm{E2}$ were lower than in media without E2. In addition to that, we also found that some fenugreek fractions could induce the expression of the estrogen-regulated gene, pS2, in MCF-7 cell. From these data, we could conclude that Fenugreek seed can exhibit both estrogenic and antiestrogenic effects in MCF-7 cells.

\section{ACKNOWLEDGMENT}

This research was supported by "Internationale Weiterbildung und Entwicklungsprogram" in Industrial Biotechnology, Germany, 2009. 


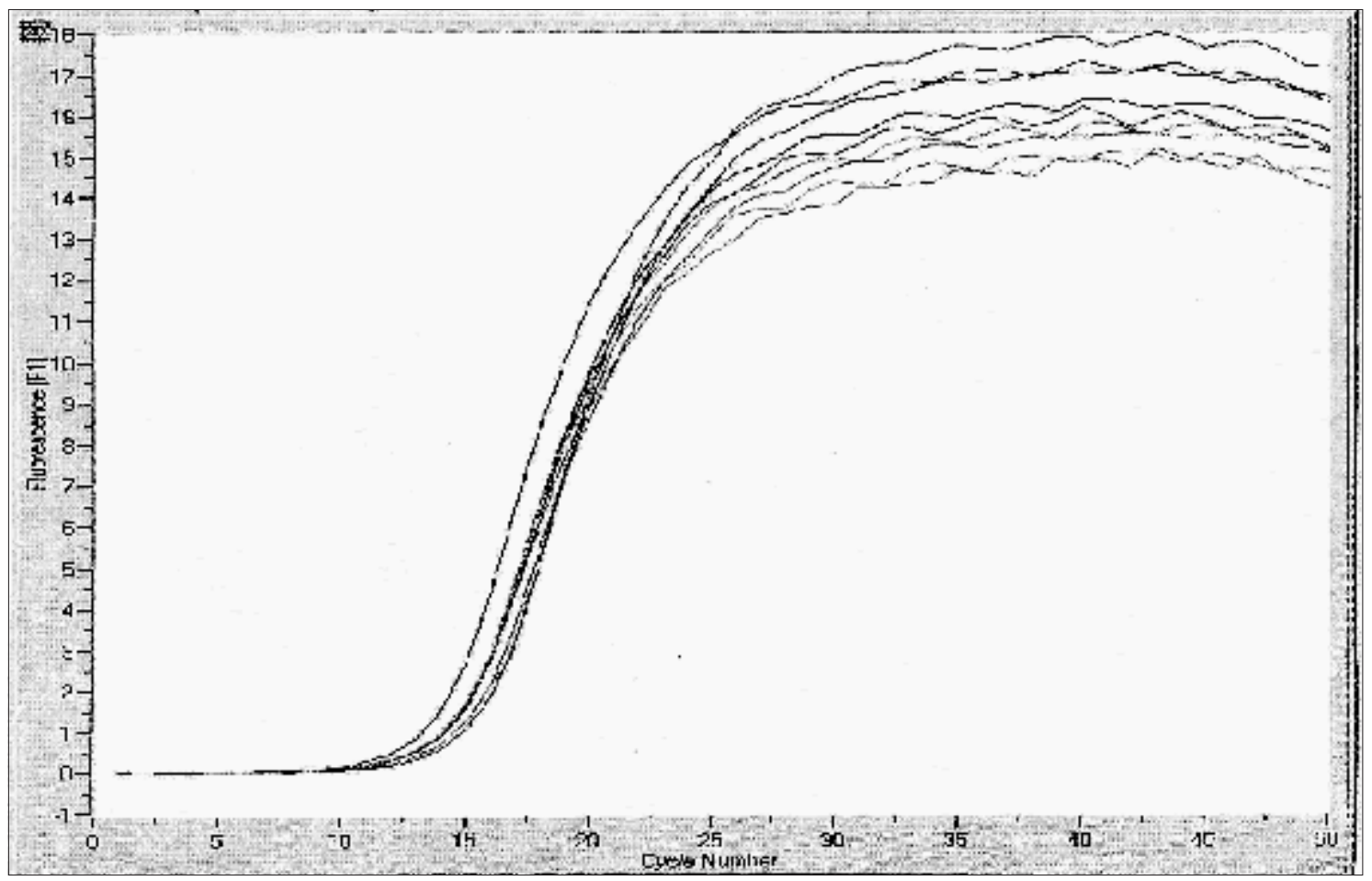

Fig. 6: Real-time-polymerase chain reaction results for pS2 in MCF-7 cells treated with estradiol (E2) and fenugreek fractions. $10 \mathrm{nM}$ E2, $20 \mathrm{ppm}$ EA2.2 fraction of fenugreek (with and without $10 \mathrm{nM} \mathrm{E2}$ ), $200 \mathrm{ppm}$ EA2.2 fraction of fenugreek

The authors would like to thank Dorothea Kauffmann, Lei Zao, and Sammy Abbas from IPMB Heidelberg for their kind help.

\section{AUTHORS' CONTRIBUTIONS}

First author is Ph.D student who contributed mostly all substantially for the research work presented in the manuscript. The first coauthor designed all the methods in the manuscript, facilitated this work in IPMB Heidelberg, helped review and improve the paper. The other coauthors are the Ph.D promotors in University of Indonesia whose directed the research, helped review, and improve the paper.

\section{CONFLICTS OF INTEREST}

All the authors have no conflict of interest. The manuscript has neither published nor simultaneously submitted for publication elsewhere. All the authors agree to the submission to the journal.

\section{REFERENCES}

1. Anonim. Materia Medika Indonesia. $3^{\text {rd }}$ ed. Jakarta: Indonesian Health Department; 1979. p. 196.

2. Anonim. WHO Monograph on Selected Medicinal Plants. Vol. 3. Otawa: WHO; 2007. p. 338-48.

3. Evans CW. Pharmacognosy. $15^{\text {th }}$ ed., Vol. 11. London: W.B. Saunders; 2002. p. 585

4. Dewick PM. Medicinal Natural Products. A Biosynthetic Approach. Vol. 10. New York: John Wiley and Sons; 1997. p. 466

5. Wiryowidagdo S. Kimia dan Farmakologi Bahan Alam. (Chemistry and Pharmacology of Natural Product). Jakarta: University of Indonesia; 2001. p. 318-28.

6. Ramesh HP, Yamaki K, Tsushida T. Effect of fenugreek (Trigonella foenum-graecum L.) galactomannan fractions on phagocytosis in rat macrophages and on proliferation and IgM secretion in HB4C5 cells. Carbohydr Polym 2002;50:79-83.

7. Jamal AJ, Ramli N, Stanslas J, Husain K. Estrogenic activity of selected Myrsinaceae species in MCF-7 human breast cancer cell. Int J Pharm Pharm Sci 2012;4:547-53.

8. Melissa PS, Navaratnam V, Yin CY. Estrogenic assessment of Labisia pumila extract using human endometrial cell line. Int J Pharm Pharm Sci 2013;5:448-52

9. Bhat KP, Lantvit D, Christov K, Mehta RG, Moon RC, Pezzuto JM, et al. Estrogenic and antiestrogenic properties of resveratrol in mammary tumor models. Cancer Res 2001;61:7456-63.

10. Oh M, Choi YH, Choi S, Chung H, Kim K, Kim SI, et al. Antiproliferating effects of ginsenoside rh2 on MCF-7 human breast cancer cells. Int J Oncol 1999;14:869-75.

11. Ali B. Endokrinologi Ginekologi. Media Aesculapius. Jakarta: Medical Faculty University of Indonesia; 2003.

12. Seidlova-Wuttke D, Hesse O, Jarry H, Christoffel V, Spengler B, Becker T, et al. Evidence for selective estrogen receptor modulator activity in a black cohosh (Cimicifuga racemosa) extract: Comparison with estradiol-17beta. Eur J Endocrinol 2003;149:351-62.

13. Rosenbaum Smith SM, Osborne MP. Breast cancer chemoprevention. Am J Surg 2000;180:249-51.

14. Johnston SR. Endocrinology and hormone therapy in breast cancer: Selective oestrogen receptor modulators and downregulators for breast cancer-have they lost their way? Breast Cancer Res 2005;7:119-30.

15. Wade C, Kronenberg F, Kelly A, Murphy PA. Hormone-modulating herbs: Implications for women's health. J Am Med Womens Assoc (1972) $1999 ; 54: 181-3$

16. Davis SR, Dalais FS, Simpson ER, Murkies AL. Phytoestrogens in health and disease. Recent Prog Horm Res 1999;54:185-210.

17. Adlercreutz CH, Goldin BR, Gorbach SL, Höckerstedt KA, Watanabe S, Hämäläinen EK, et al. Soybean phytoestrogen intake and cancer risk. J Nutr 1995; 125:757S-70S

18. Key TJ, Chen J, Wang DY, Pike MC, Boreham J. Sex hormones in women in rural China and in Britain. Br J Cancer 1990;62:631-6.

19. Wiseman H. The therapeutic potential of phytoestrogens. Expert Opin Investig Drugs 2000;9:1829-40.

20. Agustini K, Sumali W, Dadang K. Estrogenic Effect of Fenugreek (Trigonella foenum-graecum L.) on White Female Rats. Surabaya, Indonesia: Conference Proceedings Women's Health and Traditional Medicine, International Medicine and Medicinal Plants; 2007. p. 245-59.

21. Masiakowski P, Breathnach R, Bloch J, Gannon F, Krust A, Chambon P, et al. Cloning of cDNA sequences of hormone-regulated genes from the MCF-7 human breast cancer cell line. Nucleic Acids Res 1982;10:7895-903

22. Ibieta P. Interaction of Phytoestrogens with Rat Uterine Estrogen Receptor, Human Sex Hormone-Binding Globulin and Human Breast Adenocarcinoma Cells (MCF-7). PhD Thesis, Institute for Pharmacy and Molecular Biotechnology, University of Heidelberg, Germany; 2005. 